\title{
PERANAN PENGAWASAN INTERNAL DALAM RANGKA MEWUJUDKAN TATA KELOLA PEMERINTAHAN YANG BAIK
}

\author{
The Role of Internal Supervision in Order to Realize Good Governance
}

\section{Boby Segah}

Auditor Inspektorat Provinsi Kalimantan Tengah, Indonesia.

Email: bobysegah66@gmail.com

Keywords :

Role

Supervision

Good Governance

Kata Kunci :

Peranan

Pengawasan

Pemerintahan Yang Baik
Published

October 2020

\begin{abstract}
Abstrak
Tulisan ini bertujuan untuk mengetahui faktor yang akan mempengaruhi kualitas dari hasil pemeriksaan oleh pengawasan intenal yaitu Inspektorat Provinsi dan Inspektorat Kabupaten/ Kota dalam rangka mewujudkan pemerintahan nyang baik dan bersih. Mengingat, Dalam pelaksanaan pemeriksaan pengawas internal yaitu Inspektorat Provinsi dan Inspektorat Kabupaten/Kota dalam melaksanakan tugasnya didukung oleh auditor yang telah lulus sertifikasi penjengangan yang terdiri dari auditor ahli, auditor tingkat ketua tim dan auditor pengendali teknis.

Setiap audior mempunyai keahlian dan kecakapan yang professional yang memadai dalam melaksanakan tugas pemeriksaan yang secara kolektor dalam melakanakan harus memiliki pengetahuan, keahlian da pengalaman yang dibutuhkan dalam melaksanakan tugas tersebut. Pengalaman kerja, independsi, objektivitas dalam melakukan audit dapat memberikan pendapat atau kesimpulan yang apa adanya tanpa ada pengaruh dari pihak yang berkepentingan sehingga hasil pemeriksaan yang berkualitas dapat tercapai.

Hasil telaah menunjukkan bahwa Sudah selayaknya fungsi pengawasan internal lebih diberdayakan dan dilaksanakan secara sinergis demi tercapainya tujuan berbangsa dan bernegara atau good governance pada sektor publik yaitu terwujudnya transparansi, akuntabilitas, kejujuran, keadilan dan kesejahteraan masyarakat.Dengan adanya pengawasan yang dilaksanakan secara berjenjang muali dari interen SKPD sampai pemeriksaan yang dilakukan oleh eksternal (BPK) maka meminimilasi penyimpangan yang terjadi di kemudian hari menginggat pentingnya pengawasan tersebut. Dari beberapa pengalaman yang terjadi maka begitu besarnya artinya pengawasan secara berjenjang.
\end{abstract}

\section{Abstract}

This paper aims to determine the factors that will affect the quality of the inspection results by the inspectorate of the Province and The Inspectorate of District / City to realize good and clean governance. Considering, in the implementation of internal supervisory examination, namely the Provincial Inspectorate and District/City Inspectorate in carrying out its duties supported by auditors who have passed the certification of visiting consisting of expert auditors, team level auditors and technical control auditors.

Each audior has sufficient professional expertise and proficiency in carrying out inspection tasks that collectors in melakanakan must have the knowledge, expertise and experience required in carrying out the task. Work experience, independence, objectivity in conducting audits can provide opinions or conclusions as is without any influence from interested parties so that quality examination results can be achieved.

The results of the study show that it is appropriate that the function of internal supervision is more empowered and implemented synergistically to achieve the goal of national and state or good governance in the public sector namely the realization of transparency, accountability, honesty, fairness and welfare of the community. With the supervision carried out in a tiered period of nausea from the SKPD interen to external examinations (BPK) then minimizing irregularities that occur in the next day inggat the importance of such supervision. From some of the experiences that occur then so much means supervision in tiers. 


\section{PENDAHULUAN}

Pemberitaan di berbagai media masa serta tuntutan masyarakat atas penyelenggaraan pemerintahan yang baik bersih,adil, transparan dan akuntable maka hal tersebut harus disikapi secara kritis dan sitematis oleh pemeritah pada saat ini.

Segenap jajaran penyelenggaraan negara baik dari pemerintahan pusat sampai dengan pemerintah dearah serta peranan segenap jajaran penyelenggaraan negara, baik dari tatatan eksekutif, leglislatif dan yudikatif harus memiliki komitmen bersama dan sungguh - sungguh untuk menegakan pemerintahan yang baik dan bersih.

Sejalan dengan perihal tersebut, maka pemerintah pusat maupun daerah telah bersepakat untuk mencanangkan dan mengikrarkan sasaran yang akan di capai untuk meningkatkan pemberian pelayanan birokrasi kepada masyarakat degan arah kebijakan penciptaan tata pemerintahan yang bersih dan berwibawa (good governance)

Beberapa hal yang terkait dengan usaha untuk mewujudkan good governance pada sektor pemerintahan antara lain meliputi penetapan struktur organisasi dan proses pengorganisasian yang secara jelas mengatur tetang peran serta tanggungjawab akuntabilitas setiap organisasi kepada masyarakat (publik), antara lain sistem pengelolaan organisasi yang baik dan memadai serta pelaporan keuangan SKPD yang dikumpalasi menjadi laporan keuangan pemerintah pusat dan laporan pemerintah daerah Provinsi, Kabupaten dan Kota disusun berdasarkan sistem akuntansi yang sesuai dengan standard akutansi pemerintah (SAP).

Berkaitan dengan pengaturan sistem pengendalian organisasi yang baik, adalah menyangkut permasalahan tentang menajemen resiko,audit internal, pengendalian internal, penganggaran, manajemen keuangan serta pelatihan berupa bimtek atau pendidikan dan pelatihan yaitu dalam rangka peningkatan kemapuan sumber daya manusia (SDM) untuk Pegawai Negeri Sipil.
Didalam era otonomi daerah, pemerintah daerah (Pemda) telah diberikan kewenangan yang lebih luas dalam pengelolaan keuangan daerah termasuk dalam merencanakan, mengelola dan menggunakan pendapatan daerah untuk membiayai belanja dan pembiayaan daerah lainnya dalam rangka memberikan pelayanan kepada masyarakat. Pendapatan daerah terdiri dari dana transfer dari Pemerintah Pusat (untuk dana DAK) sedangkan pengaturannya telah ditentatukan oleh Kementerian/Lembaga terkait dan Pendapatan daerah yang sah.

Wujud dari transpransi dan akuntabilitas penggunaan dana tersebut, setiap tahunnya pemerintah daerah harus menyusun Laporan Keuangan yang terdiri dari Laporan Realisasi Anggaran (LRA), Neraca Daerah, Laporan Arus Kas (LAK), dan Catatan atas Laporan Keuangan (CALK) yang telah diatur dalam Undangundang Nomor I Tahun 2004 pada pasal 56 Ayat (3) tentang Perbendaharaan Negara mengamanatkan bahwa Laporan Keuangan yang disampaikan oleh Gubernur, Bupati dan Walikota kepada Badan Pemeriksa Kauangan Republik Indonesia (BPK RI) paling lambat 3 (tiga) bulan setelah tahun anggaran berakhir. Sebelum laporan keuangan tersebut disampaikan oleh Gubenur, Bupati dan Walikota terlebih dahulu dilakukan Reviuu atas laporan keuangan pemerintah darerah Gubernur, Bupati dan Walikota oleh pengawas internal (Inspektorat Provinsi, Kabupaten dan Kota)

Laporan keuangan yang disampaikan oleh Gubernur, Bupati dan Walikota tersebut adalah laporan keuangan konsolidasian (gabungan) yang merupakan laporan keuangan dari seluruh Satuan Kerja Perangkat Daerah (SKPD) masing - masing. 


\section{PEMBAHASAN}

\section{PEMERIKSAAN YANG DILAKSANAKAN OLEH EKSTERNAL (BPK RI)}

\section{Pemeriksaan yang dilaksanakan oleh Pemeriksa} Eksternal

Berdasarkan undang-undang Nomor 17 Tahun

2003 tentang Keuangan Negara pasal 3 I ayat (I), Badan

Pemeriksa Keuangan Republik Indonesia bertugas untuk melakukan reviu atas Laporan Keuangan Daerah yang disampaikan oleh Gubernur,Bupati dan Walikota selajutnya dalam Undang - undang Nomor 15 Tahun 2004 tentang Pemeriksaan Pengelolaan dan Tanggungjawab Keuangan Negara pasal 17 Ayat (2) bahwa Laporan Atas Hasil Pemeriksaan atas laporan keuangan pemerintah daerah disampaikan oleh BPK RI kepada DPRD Provinsi,Kabupaten/Kota selambatlambatnya 2 (dua) bulan setelah menerima laporan keuangan dari Pemerintah daerah.

Undang-undang di bidang Keuangan Negara yang meliputi Undang-undang Nomor

17 Tahun 2003 tentang Keuangan Negara, Undang - undang Nomor I Tahun 2004 tentang Perbendaharan Negara, Undangundang Nomor 15 Tahun 2004 tentang Pemeriksaan Pengelolaan dan Tanggunjawab Keuangan Negara beserta pendukungnya yang menggambarkan adanya keseriusan dari jajaran pemerintah (eksekuitif) dan DPRD (leglislatif) untuk ikut bersama - sama memperbaiki sistem pengelolaan keuangan pemerintah baik pemerintah daerah maupun pemerintah pusat.

Dalam peraturan mulai dari Undang - undang dan peraturan pemerintah penerbitan tersebut yang menjadi dasar bahwa keuangan negara wajib dikelola secara tertib, taat pada peraturan perundanguandangan, efisien, efektif dan ekonomis, transparan dan bertanggungjawab dengan memperhatikan rasa keadilan dan kepatutan sebagai salah satu prasyarat untuk mendukung keberhasilan dalam penyelenggaraan pemerintahan yang bersih (good goverment)

Undang - undang Nomor I5 Tahun 2004 Pemeriksaan Pengelolaan dan Tanggunjawab Keuangan Negara pasal 9 ayat (I) Dalam Penyelenggaraan
Pemeriksaan atas Pengelolaan dan Tanggungjawab Keuangan Negara, maka Badan Pemeriksa Keuangan dapat memanfaatkan hasil pemeriksaan dari Aparat Pengawasan Internal Pemerintah atau APIP seperri telah disebutkan diatas, peran dan fungsi audit internal termasuk unsur penting dalam sistem pengendalian organisasi yang memadai. Efektipitas dalam pelaksanaan audit oleh auditor ekternal sesuai dengan pasal 9 ayat (I) tersebut maka peran dan fungsi audit internal perlu diperjelas dan dipertegas.

\section{Prinsip Dasar Good Governace}

Secara terperinci kepemerintahan yang baik juga dapat menciptakan iklim keterbukaan, integritas dan akuntabilitas sesuai dengan prinsip - prinsip dasar good governance pada sektor publik.

I. Prinsip - prinsip dasar dari good governance adalah :

Pertama, keterbukaan sangat diperlukan untuk meyakinkan bahwa stakeholder memiliki keyakinan dalam proses pengembilan keputusan dan tindakan terhadap institusi pemerintah dan terhadap pengelolaan kegiatan oleh intansi pemerintah tersebut. Dalam iklim keterbukaan yang dapat dilakukan melalui proses komunikasi yang jelas, akurat dan efektip dengan pihak - pihak seperti stakeholders dapat membantu proses pelaksanaan suatu kegiatan.

Kedua, integritas mencakup dua hal pokok yaitu kejujuran dan kelengkapan informasi yang disampaikan kepada masyarakat terhadap pengelolaan sumber daya, dana dan urusan publik.

Ketiga, akuntabilitas yang merupakan bentuk suatu pertanggungjawaban setiap individu maupun secara organisasi pada institusi publik kepada pihak - pihak luar yang berkepentingan atas pengelolaan sumber daya, dana dan seluruh unsur kinerja yang telah diamankan.

Dari ke 3 (tiga) prinsip good governance tersebut diatas tercermin secara jelas dalam proses penggangaran, pelaporan keuangan dan 
pemeriksaan atas Pengelolaan Keuangan Daerah dan Negara sebagaimana tercantum dalam 3 (tiga) prinsip diatas.

Pencatatan dan pelaporan transaksi keuangan adalah merupakan salah satu bantuan dalam pemenuhan akuntabilitas dalam pelaksanaan penyelenggaraan pemerintahan yang disampaikan oleh pemerintah kepada masyarakat melalui DPR,DPRD Provinsi dan DPRD Kabupaten / Kota.

Undang - undang Nomor I Tahun 2004 dinyatakan bahwa Pengelolaan Keuangan Pemerintah baik tingkat pusat maupun daerah diwajibkan untuk meyelenggarakan sistem akutansi atas transaksi keuangan, aset, utang dan ekuitas dana, termasuk transaksi pembiayaan dan perhitungan sistem akutansi tersebut digunakan sebagai sarana dalam Penyusunan Laporan Keuangan Pemerintah Pusat/Daerah berdasarkan standard akutansi pemerintah yang berlaku.

Laporan Keuangan Pemerintah Pusat dan Daerah sekurang-kurangnya meliputi Laporan Realisasi APBN/APBD, Neraca, Laporan Arus Kas dan Catatan Atas Laporan yang dilampiri dengan laporan keiangan perusahaan negtara/daerah dan badan lainnya, selanjutnya selambat-lambatnya 3 (tiga) bulan berakhirnya tahun anggaran, Presiden selaku kepala pemerintahan di pusat dan Gubernur/Bupati/Walikota selaku kepala pemerintahan di daerah menyampaikan laporan keuangan pemerintah pusat/daerah kepada Badan Pemeriksa Kauangan (BPK RI)

Badan Pemeriksa Keuangan Republik Indonesia selaku auditor eksternal pemerintah melaksanakan audit atas laporan keuangan pemerintah pusat/daerah tersebut berdasarkan standard pemeriksaan yang berlaku. Jangka waktu pelaksanaan audit atas laporan keuangan pemerintah pusat/daerah oleh BPK RI ini sesuai dengan amanat Undang - undang Nomor 17 Tahun 2003 harus diselesaikan paling lama dalam jangka waktu 3 (tiga) bulan. Alasannya,Presiden dan Gubernur/Bupati/Walikota sudah harus menyampaikan rancangan undang - undang tentang pertanggungjawaban pelaksanaan APBN/APBD kepada DPR/DPRD Provinsi, Kabupaten/Kota berupa laporan keuangan yang telah diperiksa oleh BPK RI selambat - lambatnya 6 (enam) bulan setelah tahun anggaran berkhir. Padahal penyusunan laporan keuangan pemerintah pusat/daerah , meskipun telah menggunakan sistem akutansi keuangan yang terkomputerisasi pada umumnya masih memerlukan waktu yang cukup lama sehingga baru dapat diselesaikan dan disampaikan kepada BPK RI sekitar 3 (tiga) bulan setelah tahun anggaran berakhir sesuai dengan ketentuan yang berlaku.

Untuk dapat memenuhi jadual yang telah ditetapkan tersebut sesuai dengan amanat Undang - undang tersebut, yaitu melaksanakan audit atas laporan keuangan pemerintah pusat dan daerah praktis dalam waktu paling lama 3 (tiga) bulan tentu saja diperlukan pemanfaatan sumber daya dan dana yang tersedia pada lembaga auditor eksternal pemerintah sanggup untuk melaksanakan pekerjaan yang maha berat itu dalam waktu yang relatip sangat terbatas dan bagaimana kualitas hasil auditnya nanti dengan kendala .yang dihadapi sperti itu bagaimana pengaruhnya kepada pihak DPR, DPRD Provinsi, DPRD Kabupaten dan Kota serta masyarakat luas nantinya dalam pengambilan keputusan jika sampai terjadi pelaksanaan audit yang tidak sesuai dengan standard audit sehingga laporan hasil audit dapat menyestkan pihak - pihak yang berkepentingan dalam pengambilan keputusan terhadap pertanggungjawaban pemerintah.

Meskipun sudah ada kewajiban APIP atau Irjen Depdagri, Inspektorat Provinsi, Kabupaten dan Kota untuk melaksanakan reviu tersebut masih belum sepenuhnya dapat meningkatkan kualitas laporan keuangan pemerintah. Hal ini terbukti dari 
banyaknya laporan keuangan pemerintah baik ditingkat Provinsi, Kabupaten/Kota yang masih mendapatkan opini Wajar Dangan Pengecualian (WDP) atau opini discleamer dari BPK RI.

Menurut hemat penulis bahwa hal ini merupakan masalah yang cukup serius dan harus segera dicari alternatip jalan keluarnya sehingga jangan sampai menimbulkan kerugian pada pihak pihak tertentu yang terkait dengan permasalahan ini. Terdapat dua hal pokok yang dapat diuraikan pada bagian berkut sebagai wacana untuk meminimalisasi permasalahan yang mungkin terjadi dalam audit atas laporan keuangan pemerintah BPK RI yaitu pemberdayaan peran dan fungsi audit internal dan sinerji pengawasan diantara sesama Aparat Pengawas Intern Pemerintah (APIP)

\section{Pemberdayaan Peran dan Fungsi APIP}

Dalam penjelasan UU Nomor 15 Tahun 2004 antara lain dinyatakan bahwa untuk mewujudkan perencanaan yang komprehensif, BPK RI dapat memanfaatkan hasil pekerjaan aparat pengawasan intern pemerintah, dengan demikian, luas pemeriksaan yang akan dilakukan dapat disesuaikan dan difokuskan pada Bidang-bidang yang secara potensial berdampak pada kewajaran laporan keuangan serta tingkat efisiensi dan efektivitas pengelolaan keuangan negara. Sebagai konsekuensinya, APIP diwajibkan untuk menyampaikan laporan hasil audit yang dibutuhkan oleh BPK, tentunya diperlukan kejelasan wewenang, peran dan ruang lingkup pekerjaan yang dilaksanakan oleh APIP. Apabila hal ini diabaikan maka besar kemungkinan akan terdapat hasil pekerjaan APIP yang tidak dapat dimanfaatkan secara maksimal untuk mendukung perencanaan dan pelaksanaan audit oleh BPK.

Penulis mengakui secara jujur bahwa selama ini tugas-tugas yang dilaksanakan oleh APIP tidak hanya terbatas pada pemeriksaan saja, tetapi juga banyak melakukan fungsi pelayanan dan konsultasi dalam rangka peningkatan kinerja instansi pemerintah sesuai dengan tuntutan paradigma auditor internal yang dikehendaki pada saat ini. Hanya saja, masih sering terdengar suara sumbang yang mengecilkan peran dan arti penting APIP dapat membantu terwujudnya good governance pada sektor publik. Untuk merespon wacana yang berkembang di masyarakat tersebut, sudah tiba saatnya bagi Pemerintah Pusat dan Daerah untuk secara jelas memformulasikan ruang lingkup pekerjaan, peranan, dan kewenangan audit internal pemerintah.

Berkenaan dengan peran dan fungsi yang harus dilaksanakan oleh auditor internal dalam rangka mewujudkan good governance pada sektor publik, The Intenational Federation of Accountants (IFAC) pada tahun 200I dalam Study 13 tentang Governance in the Public Sector: A Governing Body Perspective merumuskan bahwa fungsi audit internal yang efektif mencakup reviu yang dilaksanakan secara sistematis, penilaian dan pelaporan atas kehandalan dan efektivitas penerapan sistem manajemen, keuangan, pengendalian operasional dan penganggaran, yang setidak-tidaknya meliputi berbagai aktivitas reviu sebagai berikut :

- Tingkat relevansi atas kebijakan yang ditetapkan, perencanaan dan prosedur, tingkat kesesuaian antara praktik dengan kebijakan, rencana dan prosedur yang telah ditetapkan, termasuk implikasinya terhadap aspek keuangan negara.

- Kehandalan dan keakuratan atas peraturan yang dibuat sebagai penjabaran dari peraturan yang lebih tinggitingkatannya.

- Ketepatan mengenai penyusunan struktur organisasi, pengembangan sumber daya manusia (personil) dan supervisi.

- $\quad$ Reviu terhadap pelaksanaan program dan kegiatan berdasarkan rencana yang telah ditetapkan dan manfaat atas program dan kegiatan apakah telah selaras dengan tujuan diadakannya program dan kegiatan tersebut.

- Evaluasi terhadap pertanggungjawaban dan pengamanan atas penggunaan aset dan sumber daya lainnya dan penyalahgunaan wewenang, pemborosan, kelalaian, salah urus dan lain-lainnya.

- Reviu terhadap ketepatan, keakuratan dan kejujuran atas proses pengolahan dan pelaporan informasi keuangan dan manajemen.

- Penilaian terhadap tingkat keekonomisan dan efisiensi penggunaan sumber daya.

- Penilaian terhadap integritas sistem yang terkomputerisasi berikut pengembangan sistemnya, dan 
Evaluasi terhadap tindak lanjut yang telah dilaksanakan untuk mengatasi permasalahan yang terjadi pada perioe sebelumnya.

Berdasarkan uraian diatas, tampak bahwa ruang lingkup pekerjaan audit internal sangat luas dan komprehensif agar dapat menjamin pencapaian tujuan organisasi. Penulis yakin, apabila institusi audit internal di Indonesia yang tergabung dalam wadah APIP diberikan kewenangan, peran dan fungsi yang jelas dan luas seperti tersebut diatas maka hasil pekerjaan APIP akan sangat bermanfaat tidak hanya bagi pemerintah saja, tetapi juga bermanfaat bagi pihak legislatif, eksternal auditor, dan pihak-pihak lain yang berkepentingan.

Akan tetapi, untuk menjamin kualitas hasil pekerjaan APIP yang melibatkan sekian banyak sumber daya manusia dengan berbagai jenis latar belakang pendidikan dan pengalaman, diperlukan suatu program pendidikan dan pelatihan yang profesional dan berkelanjutan. Di samping itu, untuk meningkatkan koordinasi dalam perencanaan, pelaksanaan dan evaluasi kegiatan diantara jajaran APIP, diperlukan adanya pengembangan sinergi pengawasan APIP.

\section{PEMERIKSAAN PENGAWAS INTERNAL}

Pengembangan sinergi pengawasan sesama APIP dapat dilakukan dengan cara mutual adjusment melalui koordinasi yang baik, direct supervision melalui proses peer review, serta standarisasi input, proses kerja maupun output. Selanjutnya, upaya pengembangan sinergi pengawasan APIP dapat dilakukan

Berdasarkan identifikasi masalah yang diuraikan di atas, maka pembatasan masalah dalam penulisan ini adalah "Bagaimanakah Peranan Pengawas Internal Dalam Rangka Mewujudkan Pemerintahan Yang Baik “ :

- Penajaman peran jajaran APIP dalam struktur pengawasan intern secara keseluruhan. Dalam kaitan ini, Menteri Pendayagunaan Aparatur Negara (Menpan) yang bertanggungjawab dibidang koordinasi pengawasan dapat memainkan peran sebagai strategix apex, yaitu menyinergikan gerak dan langkah pengawasan intern dalam rangka mendorong peningkatan kinerja organisasi pemerintahan dan membangun good governance. Dalam konteks penajaman peran ini pun, perlu pula dikukuhkan APIP yang secara teknis berfungsi sebagai technostructure dan middle line.

- Revitalisasi penerapan Standart Audit dan Kode Etik pada jajaran APIP.

Dengan karakteristik yang relatif spesifik mengingat basis disiplin keilmuan dan profesinya, fungsi pengawasan intern perlu merevitalisasi penerapan standart audit dan kode etik dalam pelaksanaan tugas pengawasan. Dengan penerapan standart audit dan kode etik dalam pelaksanaan tugas pengawasan. Dengan penerapan standart audit dan kode etik secara sungguh-sungguh dan konsisten, maka pola perilaku aparat pengawasan dapat terprediksi dan terkendali. $\mathrm{Hal}$ ini berarti bahwa secara tidak langsung akan terwujud standardisasi keahliaan, keterampilan dan pengetahuan sumber daya manusia pengawasan, standardisasi proses kerja pelaksanaan audit, serta standardisasi hasil kerja audit pada tataran mikro yang pada akhirnya akan berpengaruh pada tatanan makro.

- Pengembangan aturan main dan program kerja. Aturan main pelaksanaan tugas pengawasan dan program kerja APIP yang dituangkan dalam peraturan perundangan perlu disusun dan ditetapkan. Selain sebagai acuan kalangan APIP, hal ini juga diperlukan bagi pihak auditan.

- Pengembangan prosedur kerja dan dukungan teknologi informasi dan komunikasi. Prosedur kerja baku perlu dikembangkan untuk menginternalisasikan proses sinergi pengawasan, baik pada tahapan perencanaan, pelaksanaan, pelaporan, serta pemantauan dan evaluasi tindak lanjut.

Sistem pengendalian intern (SPI) merupakan syarat bagi penyelenggaraan pemerintah dan pengelolaan keuangan negara yang amanah. Sistem pengendalian intern ini pulalah, yang salah satu unsurnya adalah fungsi audit internal, yang menjadi pertimbangan penting dalam menentukan keluasan dan kedalaman ruang lingkup pekerjaan audit. Dengan demikian, fungsi audit internal yang berjalan dengan baik akan menghasilkan keluaran yang berharga untuk menjadi masukan bagi pihak auditor eksternal, eksekutif dan legislatif dalam memperbaiki pengelolaan dan pertanggungjawaban keuangan negara pada waktu yang akan datang. 


\section{KESIMPULAN}

Sudah selayaknya fungsi pengawasan internal lebih diberdayakan dan dilaksanakan secara sinergis demi tercapainya tujuan berbangsa dan bernegara atau good governance pada sektor publik yaitu terwujudnya transparansi, akuntabilitas, kejujuran, keadilan dan kesejahteraan masyarakat.

Dengan adanya pengawasan yang dilaksanakan secara berjenjang muali dari interen SKPD sampai pemeriksaan yang dilakukan oleh eksternal (BPK) maka meminimilasi penyimpangan yang terjadi di kemudian hari menginggat pentingnya pengawasan tersebut. Dari beberapa pengalaman yang terjadi maka begitu besarnya artinya pengawasan secara berjenjang.

\section{REFERENSI}

Adelia, R. (2015). Pengaruh peran auditor internal, sistem pengendalian intern pemerintah dan penyelesaian tindak lanjut temuan audit terhadap penerapan tata kelola pemerintahan yang baik good government governance: studi empiris pada sekretariat jenderal dan inspektorat jenderal di Kementerian Republik Indonesia.

Andhika, L. R. (2017). Evolusi Konsep Tata Kelola Pemerintah: Sound Governance, Dynamic Governance dan Open Government. Jurnal Ekonomi \& Kebijakan Publik, 8(2), 87-102.

Dwiyanto, Agus. (2017). Reformasi Birokrasi Publik. Gadjah Mada University Press.

Halidayati, I. (20|4). Pengaruh Pengawasan Internal, Pengawasan Eksternal Dan Implementasi Anggaran Berbasis Kinerja Terhadap Kinerja Pemerintah Daerah (Studi Empiris pada Satuan Kerja Perangkat Daerah Kota Payakumbuh). Jurnal Akuntansi, 2(2).

Kharisma, B. (2014). Good Governance sebagai Suatu Konsep dan Mengapa Penting dalam Sektor Publik dan Swasta (Suatu Pendekatan Ekonomi Kelembagaan). Jurnal Buletin Studi Ekonomi. 19(I):9-30.

Pardosi, D. A. (2018). Peran Jabatan Fungsional Auditor Terhadap Peningkatan Kinerja Birokrat Di Lingkungan Inspektorat Provinsi Jawa Tengah. Soumatera Law Review, I (2), 25 I-266.

Santoso, U. \& Pambelum, Y.J. (2008). Pengaruh Penerapan Akuntansi Sektor Publik Terhadap Akuntabilitas Kinerja Instansi Pemerintah Dalam Mencegah Fraud. Jurnal Administrasi Bisnis. 4(I): |4-33.

Saragih, J. (20I2). Reformasi Aparatur Negara untuk Melaksanakan Tata Kelola Pemerintahan yang
Baik dan Benar (Good Governance). Jurnal Ilmiah Widya, 218756.

Sari, D.N. \& Haryanto. (20|6). Analisis Determinan Efektivitas Auditor Internal pada Inspektorat Provinsi Daerah Istimewa Yogyakarta. Jurnal Akuntansi \& Auditing. 13(2): 191-210.

Segah, B. (2018). Pengaruh Pengalaman Kerja, Independensi, Objektivitas, dan Motivasi terhadap Kualitas Hasil Pemeriksaan Auditor Inspektorat Provinsi Kalimantan Tengah. Anterior Jurnal. 17(2):86-99.

Weiss, T. G. (2000). Governance, good governance and global governance: conceptual and actual challenges. Third world quarterly, 2l(5), 795814 . 